\title{
Pengaruh Penambahan Tepung Roti Afkir yang Dikombinasikan dengan Tepung Kulit Manggis sebagai Pengganti Jagung terhadap Persentase Karkas Itik Cihateup
}

\section{Effect of Addition of Wasted Bread Flour Combined with Mangosteen Peel Flour as a Substitute for Corn on Percentage of Cihateup Duck Carcasses}

\author{
Andri Kusmayadi* \\ Program Studi Peternakan, Fakultas Pertanian, Universitas Perjuangan \\ Jalan Pembela Tanah Air No. 177 Tawang - 46115, Tasikmalaya, Jawa Barat, Indonesia \\ *Corresponding author : andrikusmayadil@gmail.com
}

\begin{abstract}
ABSTRAK
Penelitian bertujuan untuk mengetahui pengaruh pemberian tepung roti afkir (TRA) yang dikombinasikan dengan tepung kulit manggis (TKM) terhadap persentase dan bagian karkas itik Cihateup. Penelitian dilakukan secara eksperimen menggunakan 84 ekor DOD itik Cihateup berjenis kelamin jantan yang dikelompokkan secara acak ke dalam 7 kelompok perlakuan yaitu R0 (Pakan tanpa perlakuan TRA dan TKM), R1 (Pakan dengan penambahan 10\% TRA + 1\% TKM), R2 (10\% TRA + 2\% TKM), R3 (20\% TRA + 1\% TKM), R4 (20\% TRA + 2\% TKM), R5 (30\% TRA + 1\% TKM), dan R6 (30\% TRA + 2\% TKM). Variabel yang diamati terdiri atas persentase karkas dan persentase bagian karkas. Penelitian menggunakan rancangan acak lengkap (RAL), data diuji menggunakan metode ANOVA dan apabila terdapat perbedaan signifikan dilanjutkan dengan uji DMRT. Hasil penelitian menunjukkan perlakuan pakan berpengaruh nyata $(P<0,05)$ terhadap persentase karkas sementara pada persentase bagian karkas tidak berpengaruh nyata. Perlakuan pakan TRA dan TKM mampu memperbaiki persentase karkas karena mengandung kadar energi yang hampir sama dengan jagung serta diperkaya dengan xanton yang dapat memperbaiki persentase karkas. Perlakuan R4 menunjukkan nilai persentase karkas yang mendekati kontrol (R0). Penambahan TRA sampai level 20\% dan 2\% TKM direkomendasikan sebagai alternatif pengganti jagung pada itik.
\end{abstract}

Kata kunci : bagian karkas, itik Cihateup, persentase karkas, tepung kulit manggis, tepung roti afkir.

\begin{abstract}
The aim of this study was to determine the effect of the administration of wasted bread flour (TRA) combined with mangosteen peel flour (TKM) on the carcass percentage of Cihateup ducks. The study was conducted experimentally using 84 male Cihateup ducks grouped randomly into 7 treatment groups: R0 (Feed without TRA and TKM treatment), R1 (Feed with the addition of 10\% TRA + 1\% TKM), R2 (10\% TRA + 2\% TKM), R3 (20\% TRA + 1\% TKM), R4 (20\% TRA + 2\% TKM), R5 (30\% TRA + 1\% TKM), and R6 $(30 \%$ TRA $+2 \%$ TKM). The observed variables consisted of the percentage of carcasses and the percentage of carcasses. The study used a complete randomized design (CRD), the data were tested using the ANOVA method and if there were significant differences followed by the DMRT test. The results showed that feed treatment had a significant effect $(P<0.05)$ on the percentage of carcasses while the part of carcasses had no significant effect. The feed containing TRA and TKM can improve the percentage of carcasses because it contains energy levels that are almost the same as corn and enriched with xanthones which can improve the percentage of carcasses. The treatment of R4 shows the value of the percentage of carcasses that are close to control (R0). The addition of TRA to the level of $20 \%$ and $2 \%$ TKM is recommended as an alternative to corn in ducks.
\end{abstract}

Key words : Carcasses, Carcass percentage, Cihateup duck, Mangosteen peel, Wasted bread. 


\section{PENDAHULUAN}

Jagung merupakan sumber energi utama bagi ternak unggas yang kontribusinya mencapai $40-60 \%$ dari total ransum. Ketersediaan jagung masih sebagian besar berasal dari impor sehingga menyebabkan harga jagung yang relatif semakin mahal. Data importasi jagung di Indonesia cenderung semakin meningkat, dimana angka importasi pada Tahun 2015 mencapai 3.267.694 ton (Pusat Data dan Sistem Informasi Pertanian, 2016). Masalah ini perlu dicarikan solusinya dengan mensubstitusi jagung dengan sumber energi yang lain seperti roti afkir. Roti afkir memiliki ketersediaan yang melimpah dimana di pasar tradisional di Kecamatan Rajapolah Kabupaten Tasikmalaya ditemukan sebanyak $10 \mathrm{~kg}$ roti afkir dalam sehari. Roti afkir berpotensi limbah karena belum ada yang memanfaatkannya. Ketersediaan roti afkir yang berpotensi limbah tersebut perlu dimanfaatkan dengan mengolahnya menjadi tepung roti afkir. Tepung roti afkir sangat potensial dijadikan sebagai sumber energi pakan unggas mengingat kandungan energi metabolisnya mencapai 2952 $\mathrm{kkal} / \mathrm{kg}$ (Widjastuti et al., 2009). Selain itu, tepung roti afkir memiliki nilai nutrisi yang masih lengkap sehingga layak dijadikan sebagai pakan ternak unggas. Kandungan nutrisi roti afkir terdiri atas protein sebesar $6,1 \%$, lemak kasar $7,5 \%$ dan serat kasar 4,7\% (Winarti dan Supriadi, 2014).

Itik Cihateup sebagaimana unggas pedaging lainnya membutuhkan sumber energi yang cukup tinggi untuk pertumbuhan dan produksi daging. Pemanfaatan tepung roti afkir sampai level 30\% dilaporkan mempengaruhi persentase karkas meskipun tidak berpengaruh nyata terhadap pertambahan bobot badan (Hidayatullah et al., 2016). Masalah ini perlu alternative solusi lain agar pemanfaatan roti afkir menjadi lebih signifikan salah satunya dengan menambahkan imbuhan pakan. Imbuhan pakan ternak yang berasal dari herbal terbukti memiliki dampak positif terhadap produktivitas maupun kualitas karkas yang dihasilkannya. Pemanfaatan tepung kulit buah manggis memiliki pengaruh yang baik terhadap kinerja pertumbuhan, profil lipid dan lemak abdominal itik Cihateup dibandingkan kontrol (Kusmayadi et al., 2019). Selain itu, Fitria et al. (2014) menambahkan bahwa tepung kulit manggis memiliki dampak yang baik terhadap pertumbuhan dan produksi karkas ayam broiler.
Penggunaan roti afkir sebagai substitusi jagung dalam ransum itik Cihateup yang dikombinasikan dengan tepung kulit manggis diharapkan memiliki dampak positif dalam memperbaiki permasalahan itik. Pada penelitian ini akan dikaji pengaruh penambahan tepung roti afkir yang dikombinasikan dengan tepung kulit manggis terhadap persentase karkas itik Cihateup.

\section{MATERI DAN METODE Materi Penelitian}

Limbah roti afkir yang didapatkan dari Pasar Rajapolah, Kabupaten Tasikmalaya. DOD itik Cihateup yang didapatkan dari penetasan "Kelompok Ternak Megar Bebek Cihateup", bahan pakan (Tabel 1), air galon, oven, timbangan, tempat pakan dan air, mesin giling dan kandang metabolis.

Tabel 1. Susunan Bahan Pakan dan Kandungan Nutrisinya

\begin{tabular}{lcc}
\hline \multicolumn{1}{c}{ Uraian } & $\begin{array}{c}\text { Starter } \\
(\%)\end{array}$ & Grower (\%) \\
\hline Jagung & 45,00 & 55,00 \\
Bungkil kedelai & 21,50 & 16,00 \\
Dedak & 5,00 & 9,00 \\
Tepun ikan & 3,00 & 3,00 \\
Minyak & 3,00 & 1,00 \\
Garam & 0,35 & 0,35 \\
Kapur & 1,00 & 1,00 \\
Premix & 0,50 & 0,50 \\
Lisin & 0,10 & 0,10 \\
Metionin & 0,10 & 0,10 \\
Kandungan nutrisi & & \\
Protein kasar (\%) & 18,35 & 16,21 \\
Lemak kasar (\%) & 10,87 & 10,15 \\
Serat kasar (\%) & 6,67 & 7,42 \\
BETN (\%) & 51,05 & 53,11 \\
Energi & 2867 & 2885 \\
Ca & 0,80 & 0,80 \\
P & 0,35 & 0,35 \\
\hline
\end{tabular}

Sumber: Kusmayadi (2019)

\section{Prosedur Penelitian}

Penelitian dilakukan secara selama 56 hari menggunakan 84 ekor DOD itik Cihateup secara acak dikelompokkan ke dalam 7 kelompok perlakuan pakan yaitu: $\mathrm{R} 0=$ Pakan tanpa perlakuan TRA dan TKM, R1 $=10 \%$ TRA + $1 \% \mathrm{TKM}, \mathrm{R} 2=10 \% \mathrm{TRA}+2 \% \mathrm{TKM}, \mathrm{R} 3=20 \%$ TRA $+1 \%$ TKM, R4 $=20 \%$ TRA $+2 \%$ TKM, R5 $=30 \%$ TRA $+1 \%$ TKM dan R6 $=30 \%$ TRA $+2 \%$ TKM. Variabel yang diukur yaitu persentase dan 
bagian karkas menggunakan metode Swatland (1984).

Analisis Data
Data hasil penelitian dianalisis menggunakan ANOVA (Gasperz, 1991). Apabila terdapat perbedaan yang signifikan dilanjutkan dengan uji DMRT (Subali, 2010).

\section{HASIL DAN PEMBAHASAN}

Tabel 2. Hasil perlakuan pakan

\begin{tabular}{|c|c|c|c|c|c|c|c|}
\hline Perlakuan & $\begin{array}{l}\text { Bobot Potong } \\
\text { (g) }\end{array}$ & $\begin{array}{l}\text { Bobot Karkas } \\
\text { (g) }\end{array}$ & $\begin{array}{l}\text { Persentase } \\
\text { Karkas (\%) }\end{array}$ & $\begin{array}{c}\text { Dada } \\
(\%)\end{array}$ & $\begin{array}{c}\text { Sayap } \\
(\%)\end{array}$ & $\begin{array}{c}\text { Punggung } \\
(\%)\end{array}$ & $\begin{array}{c}\text { Paha } \\
(\%)\end{array}$ \\
\hline R0 & $1225.75 \pm 40.51^{b}$ & $711.50 \pm 40.70^{b}$ & $58.04 \pm 2.39^{b}$ & $28.18 \pm 1.71$ & $18.31 \pm 1.44$ & $30.77 \pm 3.44$ & $22.73 \pm 1.82$ \\
\hline $\mathrm{R} 1$ & $1195.75 \pm 44.54^{b}$ & $680.75 \pm 49.93^{\mathrm{ab}}$ & $56.84 \pm 5.60^{a}$ & $27.49 \pm 0.87$ & $19.90 \pm 2.31$ & $31.46 \pm 3.21$ & $21.15 \pm 1.44$ \\
\hline $\mathrm{R} 2$ & $1211.50 \pm 28.38^{b}$ & $685.00 \pm 52.54^{b}$ & $56.54 \pm 5.31^{a}$ & $27.47 \pm 0.78$ & $19.73 \pm 2.67$ & $30.75 \pm 3.73$ & $22.05 \pm 2.51$ \\
\hline R3 & $1214.25 \pm 60.62^{b}$ & $696.50 \pm 37.67^{b}$ & $57.36 \pm 4.40^{\mathrm{ab}}$ & $26.87 \pm 1.33$ & $20.48 \pm 1.83$ & $31.55 \pm 2.18$ & $21.09 \pm 1.21$ \\
\hline $\mathrm{R} 4$ & $1223.00 \pm 54.74^{b}$ & $705.25 \pm 22.36^{b}$ & $57.67 \pm 3.12^{\mathrm{b}}$ & $27.55 \pm 1.28$ & $20.04 \pm 1.79$ & $31.52 \pm 1.93$ & $20.89 \pm 0.88$ \\
\hline R5 & $1166.25 \pm 77.22^{a}$ & $658.75 \pm 37.12^{\mathrm{a}}$ & $56.48 \pm 2.33^{a}$ & $27.70 \pm 0.74$ & $20.33 \pm 1.57$ & $31.03 \pm 1.12$ & $20.94 \pm 0.97$ \\
\hline $\mathrm{R} 6$ & $1182.50 \pm 65.08^{a}$ & $677.75 \pm 23.56^{\mathrm{ab}}$ & $57.32 \pm 2.56^{\mathrm{ab}}$ & $28.76 \pm 0.82$ & $20.14 \pm 0.94$ & $29.85 \pm 2.17$ & $21.25 \pm 0.46$ \\
\hline
\end{tabular}

Keterangan: $\mathrm{R} 0=$ Pakan tanpa perlakuan (TRA dan TKM), R1A = 10\% TRA + 1\% TKM, R1B = 10\% TRA + 2\% TKM, R2A = 20\% TRA + 1\% TKM, R2B $=20 \%$ TRA + 2\% TKM, R3A $=30 \%$ TRA + 1\% TKM, R3B $=30 \%$ TRA + 2\% TKM.

${ }^{a, b}$ Superskrip pada kolom yang sama menunjukkan perbedaan signifikan $(P<0,05)$

Hasil penelitian pada Tabel 2 menunjukkan bahwa perlakuan pakan berpengaruh signifikan terhadap bobot potong itik Cihateup. Perlakuan Ro tidak berbeda nyata dengan R1, R2, R3 dan R4. Hal ini menunjukkan bahwa bobot potong itik Cihateup perlakuan kontrol sama dengan R1, R2, R3 dan R4. Hal ini dapat disebabkan oleh konsumsi pakan pada perlakuan $\mathrm{R} 1, \mathrm{R} 2, \mathrm{R} 3$ dan $\mathrm{R} 4$ tidak berbeda atau sama dengan R0. Akan tetapi pada perlakuan R5 dan R6 yang mengandung TRA lebih tinggi menunjukkan penurunan bobot potong. Hasil ini sesuai dengan penelitian Hidayatullah et al. (2016) yang melaporkan bahwa penggunaan tepung limbah roti tawar pada level tinggi $(60 \%)$ sebagai pengganti jagung dapat menurunkan konsumsi pakan. Penurunan konsumsi pakan dapat mengakibatkan pertumbuhan menjadi lambat dan akhirnya berpengaruh terhadap bobot potong itik Cihateup.

Berdasarkan data pada Tabel 2. perlakuan R4 yang mengandung TRA sebanyak $20 \%$ yang dikombinasikan dengan TKM menghasilkan bobot potong yang paling mendekati perlakuan Ro. Hal tersebut menunjukkan bahwa pemberian perlakuan TRA sampai level $20 \%$ memiliki dampak positif terhadap pertumbuhan ternak sehingga memiliki nilai bobot potong yang cukup tinggi dan mendekati perlakuan kontrol. Widjastuti (2009) melaporkan bahwa tepung roti afkir masih memiliki sumber energi yang baik sehingga dapat meningkatkan palatabilas ternak. Hal ini disebabkan oleh komposisi bahan penyusun roti mengandung susu. Susu mengandung laktosa yang dapat dijasikan sebagai media pertumbuhan bagi bakteri probiotik seperti lactobacillus di dalam saluran pencernaan unggas. Lactobacillus di dalam usus unggas akan menghasilkan asam laktat yang dapat meningkatkan sekresi garam empedu ke dalam usus halus. Dengan demikian, usus halus dapat memperbaiki dan meningkatkan metabolisme selnya sehingga menyebabkan peningkatan penyerapan nutrien pakan di dalam usus halus. Oleh karena itu, penyerapan zat-zat tersebut akan semakin efektif dan efisien sehingga akan memperbaiki bobot badan ternak.

Penambahan tepung kulit manggis dosis lebih tinggi (2\%) pada ransum yang mengandung TRA turut berkontribusi dalam meningkatkan bobot potong itik Cihateup. Hal ini ditunjukkan pada perlakuan R2, R4 dan R6 yang memiliki bobot potong lebih tinggi dibandingkan perlakuan TRA pada dosis $1 \%$. Hal ini dikarenakan dosis $2 \%$ merupakan level optimum dalam meningkatkan sistem pencernaan yang efektif dengan mempengaruhi populasi mikroflora usus halus agar tetap seimbang populasinya karena kulit manggis mengandung xanton yang berperan sebagai antimikroba patogen (Erhan et al., 2012). Dengan demikian, saluran pencernaan 
menjadi lebih sehat sehingga berdampak terhadap pembentukan daging yang lebih cepat yang ditandai dengan meningkatnya bobot potong.

Penambahan TRA dan TKM pada perlakuan $\mathrm{R} 2$, $\mathrm{R} 3$ dan $\mathrm{R} 4$ memiliki pengaruh positif dalam memperbaiki bobot karkas sehingga mendekati kontrol (R0). Hal ini disebabkan komposisi nutrisi pada jagung maupun roti afkir mengandung karbohidrat dan protein yang hampir sama sehingga menyebabkan respon tubuh ternak terhadap kecernaan pakan hampir sama sehingga berdampak pada bobot karkas yang hampir sama pula. Nilai kecernaan pada pati tepung terigu sebesar $97,42 \%$ sementara pada pati jagung sebesar 95,84\% (Hidayatullah et al., 2016). Bahan baku pembuatan roti adalah tepung yang mengandung pati yang mudah dicerna oleh saluran pencernaan sehingga lebih mudah membentuk otot (daging).

Ramina (2001) menambahkan bahwa kandungan protein dalam ransum yang seimbang dan sesuai kebutuhan dapat meningkatkan bobot dan persentase karkas. Hal ini disebabkan asupan asam-asam amino di dalam tubuh terpenuhi sehingga menyebabkan proses metabolism sel di dalam tubuh berlangsung baik yang selanjutnya akan berdampak pada meningkatnya bobot karkas. Selain itu, penambahan tepung kulit manggis pada ransum yang mengandung TRA memiliki kontribusi yang cukup baik dalam memperbaiki bobot karkas (Faishal et al., 2013). Adapun pemberian TKM dengan dosis $2 \%$ pada berbagai perlakuan memiliki nilai bobot karkas yang lebih tinggi dibandingkan $1 \%$. Hal ini disebabkan oleh kandungan xanton pada TKM dosis $2 \%$ memiliki jumlah yang optimal untuk memperbaiki bobot karkas itik. Senyawa xanton pada TKM berperan sebagai antioksidan yang dapat mencegah dan meminimalisir radikal bebas tubuh (Kusmayadi, 2019) sehingga ternak tidak mudah mengalami stress. Hal ini menyebabkan bobot karkas tetap stabil.

Perlakuan R0 tidak berbeda nyata dengan R3, R4 dan R6 pada parameter persentase karkas (Tabel 2). R3, R4 dan R6 mengandung kadar energi dan xanton pada level optimal sehingga memiliki persentase karkas yang sama dengan kontrol. Hasil ini sejalan dengan Widjastuti et al. (2009) bahwa pemberian tepung limbah roti sampai level 30\% dalam ransum masih dapat direspons dengan baik oleh ayam broiler. Penambahan TKM pada ransum itik berperan sebagai pemacu pertumbuhan sehingga ternak tidak mengalami stress oksidatif yang akan berdampak pada pembentukan otot dan daging (Kusmayadi et al., 2019). Xanton yang terkandung dalam kulit manggis memiliki dampak yang baik terhadap kesehatan tubuh ternak. Kondisi tubuh itik yang sehat akan memberikan respon konsumsi pakan yang meningkat pula sehingga bobot badan itik berkolerasi positif pada peningkatan persentase karkas (Putri, 2014).

Data pada Tabel 2. menunjukkan bahwa perlakuan pakan tidak berpengaruh nyata $(P>0.05)$ terhadap persentase bagian karkas. Hal ini menunjukkan bahwa persentase bagian karkas tidak dipengaruhi oleh penambahan tepung roti afkir dan kulit manggis.

\section{KESIMPULAN}

Penambahan TRA pada pakan itik Cihateup sampai level 20\% dan TKM sampai level $2 \%$ mampu memperbaiki persentase karkas namun tidak mempengaruhi persentase bagian karkas.

\section{DAFTAR PUSTAKA}

Erhan, M.K., Bölükbaşi, Ş.C., and Ürüşan, H. 2012. Biological activities of pennyroyal (Mentha pulegium L.) in broilers. Livest. Sci., 146(2):189-192.

Faishal, I. J., Djunaidi, I. H., and Sudjarwo, E. 2013. Effect of addition mangosteen peel powder (Garcinia mangostana $L$ ) to feed on carcass and internal organs mojosari drake. Jurnal Brawijaya 5(1): 1 - 10.

Fitria, S., Maharani, S., Supadmo, S., Suprizal, Z. 2014. pengaruh penambahan tepung kulit manggis (Garcinia mangostana L.) sebagai aditif pakan terhadap pertumbuhan dan produksi karkas ayam broiler. Buletin Peternakan 38(2):83-89.

Gaspersz, 1991. Teknik Analisis dalam Penelitian Percobaan. Tarsito: Bandung

Hidayatullah, M.F., Djunaidi, H.I., Natsir, H. 2016. Efek penggunaan tepung limbah roti tawar sebagai pengganti jagung terhadap penampilan produksi itik hibrida. Jurnal Universitas Brawijaya. HIm 1 - 11. 
Kusmayadi, A. 2019. Pengaruh kombinasi tepung roti afkir dan tepung kulit manggis sebagai substitusi jagung dalam ransum itik cihateup terhadap performan pertumbuhan dan income over feed cost. Jurnal Peternakan. 16 (2): $43-48$.

Kusmayadi, A., Bachtiar, K.R. and Prayitno, C.H. 2019. The effects of mangosteen peel (Garcinia mangostana L.) and turmeric (Curcuma domestica Val) flour dietary supplementation on the growth performance, lipid profile, and abdominal fat content in Cihateup ducks. Veterinary World 12(3):402-408.

Pusat Data dan Sistem Informasi Pertanian. 2016. Outlook Komoditas Pertanian Tanaman Pangan Jagung. Kementerian Pertanian RI.

Putri, R.A., Busono, W., dan Widodo, E. 2014. Effect of turmeric extract (Curcuma domestica $\mathrm{Val}$ ) on percentage of carcass, percentage of abdominal fat and meat cholesterol levels in hybrid ducks. Jurnal Brawijaya 6 (1) : 1 - 10.

Ramina, I.K. 2001. Suplementasi probiotik dalam ransum berprotein rendah terhadap bobot dan komposisi fisik karkas. karya ilmiah. Majalah IImiah Peternakan. Fakultas Peternakan. Universitas Udayana. Denpasar.

Subali, B. 2010. Aplikasi statistik menggunakan program SPSS aplikasinya dalam rancangan percobaan. Jurusan Pendidikan Biologi, FMIPA UNY. Yogyakarta.

Swatland, H. J. 1984. Structure and Development of Mea Animals. Prentice-Hall. Inc. Englewood Cliffs. New Jersey

Widjastuti, T., Sujana, E. 2009. Pemanfaatan tepung limbah roti dalam ransum ayam broiler dan implikasinya terhadap efisiensi ransum dan IOFC. Prosiding Seminar Nasional Fakultas Peternakan Unpad. 558-562.

Winarti E, Supriadi. 2104. Pengaruh penggantian jagung dengan roti afkir dalam pakan komplit terhadap pertambahan bobot badan sapi Peranakan Ongole. Prosiding Semnas Teknologi Peternakan dan Veteriner. Malang, 12-14 Agustus 2014.
Pusat Penelitian dan Pengembangan Peternakan. Hal. 178 - 183. 